\title{
Diaspora without Homeland: A Review
}

Diaspora without Homeland: Being Korean in Japan. Edited by Sonia Ryang and John Lie (Berkeley and Los Angeles: University of California Press, 2009), 229 pp., ISBN 9780520098633 , US \$29.95.

\section{Shota Ogawa*}

Diaspora without Homeland is a cross-disciplinary collection of articles that brings together different, at times conflicting, perspectives on Koreans in Japan under a shared acknowledgment of the necessity to respond to the rapidly changing conditions surrounding them. Much has been written on Koreans in Japan since Changsoo Lee and George De Vos's pioneering work Koreans in Japan: Ethnic Conflict and Accommodation (University of California Press, 1981), partly as a reaction against the proliferation of Nihonjinron (literally 'theories on the Japanese,' popular literature that emphasizes the uniqueness of Japanese culture) in the 1980s. The historical presence of the approximately 600,000 Koreans in Japan, particularly that of the so-called 460,000 "oldcomers" (colonial subjects brought to Japan before 1945 and their descendents) became a living proof for scholars aiming to counter Nihonjinron theorists and their belief in Japan's homogeneity.

The book's framing of the Koreans in Japan as a diasporic group marks a departure from the traditional treatment of them as Japan's minorities. Due to Japan's jus sanguineous nationality law, even Japan-born descendents of "old comer" Koreans are excluded from national membership which renders the term "Japan's minority" problematic. The turn to "diaspora" stresses the group's exteriority to Japan, but also offers an escape from the discourse that prescribes assimilation and naturalization as the condition for any improvements of the group's status. The co-editors Sonia Ryang and John Lie insist on the book's heterogeneity which purportedly resists an "academic resolution" over political differences. Faithful to this spirit, the book opens with Ryang's introduction and her separate chapter which stress the vulnerability that comes with Koreans' exclusion from Japan's polity and ends with Lie's counter-argument that urges the readers to look beyond the clichéd image as "the oppressed and pathetic" colonial victims toward their future that exists in Japan. The book draws its strength from its highly ambiguous definition of diaspora that highlights the discontinuous relation Koreans in Japan have to existing nation-states as well as to the very label of "Koreans in Japan." Most contributors thus engage the discourses of diaspora critically, which marks the book's departure from its closest predecessor, the special issues of Korean and Korean American Studies Bulletin (Vol 11,12, 2000, 2001), also featuring Ryang and Lie, which literally mapped out the Korean diaspora - the fourth largest in the world as the issue editor Hesung Chun Koh stresses - in sections that are divided according to four large Korean diasporas in the United States, Japan, China, and Central Asia.

Ryang qualifies the book's turn to diaspora by defining diasporic discourses as heterogeneous, or "promiscuous" sets of theories that destabilize their own parameters (2).

\footnotetext{
* Shoto Ogawa is a graduate student at the University of Rochester (Email: shota.ogawa@gmail.com).
} 
To discuss Koreans in Japan as diasporic people is thus different from framing them within the discourse of the "Korean diasporas" as Koh's special issues did. Ryang identifies two models of diaspora studies: the "classical" model of diaspora studies exemplified by the Jewish Diaspora founded on "a strong sense of connection to home;" and the newer "cultural studies" model which stresses the "on-going crisis of identity" related to "the loss of an original homeland" (2). While her notion of the "promiscuous" diaspora as well as the use of terms such as "routes" suggest her bias toward the "cultural studies" mode of James Clifford and Paul Gilroy, she aims to carve out a middle ground based on the equal measure of emphasis both models place on the idea of a lost homeland. To this extent, Ryang's investment in the notion of diaspora should be understood differently from the popular idea of "Korean diasporas" which frames heterogeneous diasporas as satellite communities of Korea proper, and also from an expansive interpretation of diaspora formed around various forms of displacement not necessarily away from "homeland."

Ryang's investment in the idea of "homeland" is peculiar given that much of the contemporary writing on Koreans in Japan attempts to circumvent the problem of the North and South division of Korea which traditionally ran deep in the Korean communities of Japan. This trend has informed the choice of terms used to denote the group. The traditional term zainichi chosenjin, which technically denoted "Koreans" in Japan, gradually came to refer to North Koreans in Japan while a separate term zainichi kankokujin was coined for South Koreans. In order to avoid the impression of political bias, scholars and the public prefer to use the shortened version: zainichi, simply meaning "in Japan" without the subject. Among the contributors to Diaspora without Homeland, the trend to shy away from homeland-orientation (sokoku shiko) is evident in Youngmi Lim's case study on naturalized Koreans ("Korean Roots and Zainichi Routes"). Lim shows her commitment to this by conducting her fieldwork without using "homeland State-based organizational channels" such as Chongryun and Mindan (organizations with affiliations to North and South Korea respectively.

We find a hint for understanding Ryang's seemingly anachronistic turn to "homeland" in her chapter contribution titled "Visible and Vulnerable: The Predicament of Koreans in Japan." The chapter is evidently a hastily written piece, prompted by an impending sense of emergency in the face of the deteriorating environment for Koreans in Japan following Kim Jon-il's surprise admission of kidnapping a total of thirteen Japanese civilians in 2002. This so-called 9/17 crisis caused a sharp increase in hate crimes against Koreans in Japan - most notably against female students of schools run by Chongryun (the General Association of Korean Residents in Japan), whose ethnic school uniforms make them highly visible and vulnerable, while the male students are able to pass for Japanese in their Japanese-style school uniforms. Alarmed by the media's labeling of Chongryun students as "loyal followers of the Kim regime," Ryang asserts that the students as well as most Chongryun employees and associated members are "accidental affiliates" of Chongryun, rather than Kim's sympathizers by choice (64). The deteriorating tolerance toward anyone affiliated with Chongryun compels Ryang to make a contradictory move to question the capacity of a country with such "deep and profound" racism as Japan to host diasporic communities. Diaspora in this context is no longer a descriptive term, but a utopian, unrealized horizon, akin to Ryang's notion of "homeland" that must always remain an idea (79). The moment the "homeland" becomes conflated with an actual place such as North Korea - as it was the case in the 1980s when Chongryun association members were at last allowed to travel abroad in- 
cluding to their "glorious socialist fatherland" - the diaspora loses its appeal. The thousands who visited North Korea had to confront the gap between the idealized "fatherland," perpetuated through Chongryun propaganda, and the actual impoverished and hierarchical country. The travel back to the "homeland," which Chongryun avidly encouraged, ironically diminished Chongryun's authority and sped its decline (66-67).

The two chapters by Mark E. Caprio and Yu Jia, and Tessa Morris-Suzuki add another dimension to diaspora discourses through their research which spans multiple countries. Despite the title, "Occupations of Korea and Japan and the Origins of the Korean Diaspora in Japan," Caprio and Jia prompt us to look further back to the preOccupation history wherein U.S. intelligence agency activities resulted in the "origin" of the Korean diaspora. They cite fascinating testimonies (collected by the U.S. military in preparation for their postwar policies) by Korean prisoners of war who had fought in the Japanese army. The U.S. officials appear to have been successful in eliciting honest comments from the Korean POWs regarding the degrees of hatred Korean people felt toward the Japanese, Koreans working for the Japanese police, and those working for the Japanese in other capacities. While these testimonies offer important insights, it would add another dimension to the study of Korean diasporas if it was stated in what language these interviews were conducted and whether there were any Koreans (or Japanese) in the U.S. involved in the process. Despite these intelligence activities, however, the rest of the chapter makes clear that the Occupation eventually conformed to the Japanese administration's treatment of Koreans in Japan and Korean nationals as communist elements.

Tessa Morris-Suzuki's chapter, "Freedom and Homecoming: Naratives of Migration in the Repatriation of Zainichi Koreans to North Korea," complicates the book's focus on diaspora through her historiographical analysis of the "repatriation" of some 90,000 Koreans and their Japanese family members from Japan to North Korea between 1959 and 1984. The rhetoric of "homecoming," on which diasporic discourses are founded, has naturalized the "repatriation" even though the great majority of the "repatriated" were from the southern part of the Korean peninsula (40). Morris-Suzuki raises the "age-old conundrum of freedom versus determinism," which is central to so many historical narratives of migration. The boundary between voluntary migration and imposed relocation becomes blurred through Morris-Suzuki's case studies such as those of a woman who secured parole on the condition of repatriating, a Japanese woman separated from her Korean spouse who chose to "repatriate" for her son's well-being, and a psychiatric ward escapee who claimed to have been unjustly hospitalized despite being sane. The individual stories are corroborated by Morris-Suzuki's "another story" method woven from public documents, including newly declassified records kept by the International Committee for the Red Cross (ICRC). What emerges is a continuity between Capri and Jia's study of the postwar Yoshida government's determination to "rid" Japan of Koreans and the repatriation project which eventually won the support of ICRC and consequently the status of "a praiseworthy act of humanitarianism" (46). The repatriated Koreans did not find "home," but a further complication of their diasporic condition. The conundrum of free choice versus imposed relocation is also evident in the complexity involved in the visibility/vulnerability of the female students in Ryang's study. The visibly Korean outfit is imposed on the Female Chongryun students today due to a deep patriarchal bias running through Chongryun. An historical investigation into the origin of the female uniforms, however, complicates the picture, for the uni- 
forms were originally designed by a group of female students in order to make their presence visible in the hitherto male-dominated sphere of higher education.

Youngmi Lim's “Korean Roots and Zainichi Routes: the Invisible Diaspora among Naturalized Japanese of Korean Descent" also addresses the tension between individual and collective dimensions, but probes more deeply in order to question the limits of diaspora discourses. Lim's contribution is important, first of all, for considering the traditionally overlooked group of Koreans who have naturalized to Japanese and noting the alienation these Koreans experience from both Japanese society and the Korean community in Japan. Lim observes most scholars' subconscious bias toward "organized" zainichi Koreans who are more visible and accessible than the perspectives of the "invisible diaspora" exemplified by naturalized ex-Zainichi. This criticism is applicable to discourse on diaspora even in its most expansive form so long as it necessitates some notion of "diasporic consciousness." Such consciousness is absent in the subjects of Lim's study who "do not imagine themselves part of the zainichi diaspora" even though they "have not found a secure 'homeland' in their country of birth and residence over generations" (103). Ultimately, for Lim, diaspora is a "theoretical tool" which allows her to resist the conventional teleological scenario of immigration that assumes all immigrants to sooner or later follow the trajectory of assimilation (104). Lim persuasively illustrates the problems in Ryang's ambiguous notion of diaspora, which mystifies its own exclusive structure behind its supposedly open-ended indeterminacy. From the interviews with Koreans with Japanese nationality, however, their position appears so different from the Koreans who insist on the notion of homeland that we are left to wonder what we are gaining from considering the two groups under the rubric of diaspora.

The chapters by Kashiwazaki ("The Foreigner Category for Koreans in Japan: Opportunities and Restraints") and Erin Aeran Chung ("The Politics of Contingent Citizenship: Korean Political Engagement in Japan and the United States') complicate the issue of the exteriority of Koreans in Japan in relation to full membership in Japanese society. Kashiwazaki persuasively demonstrates the uniquely positive value Koreans are able to confer upon their "outsider" status by actively playing on their "foreignness" by identifying with people from various foreign countries. Chung, on the other hand, offers a fascinating comparative study between Koreans in Japan and America and juxtaposes the contingent citizenship and vocal foreignness. The two chapters suggest a more positive reassessment of exteriority than Ryang's dystopian assessment of the post-9/17 political climate surrounding the largely assimilated Koreans in Japan who nonetheless find themselves excluded from Japanese state protection. Kashiwazaki notes the numerous "instances in which the word foreigner (gaikokujin) is being used as a positive categorical term" in the present political climate: Foreigners are residents, too, Living together with foreigners, and Local electoral rights for resident foreigners (121) Such identification with foreignness is peculiar since Japan-born Koreans are culturally closer to the Japanese than to other foreigners. Through historical analysis, Kashiwazaki demonstrates that Koreans in Japan have always strategically employed a rhetoric of foreignness.

In the immediate postwar years, the U.S. Occupation Command and the Japanese government placed Koreans in a legal gray area with rights between those of Allied citizens and Japanese subjects so that they could be treated at once as Japanese nationals in terms of criminal jurisdiction (including war crime trials) and as foreign nationals under the new immigration control devices symbolized by their vulnerability to forced deportation. In such circumstances, the identification with "foreignness" was a "resistance 
against the daisangokujin (the third-country national) category" (130). Today, the "foreign" category is effectively employed in local-level activism that circumvents the North-South or newcomer-oldcomer divides. As Kashiwazaki notes, foreign nationals regardless of birthplace or degree of cultural assimilation share many hurdles including housing discrimination and compulsory finger-printing as part of Alien Registration (138). Her chapter, however, does not elaborate on the limits of the collective identification with foreignness in relation to the post-9/17 climate of intolerance symbolized by the Abe government's clampdown on Chongryun through searches and arrests as well as the Tokyo Governor Ishihara Shintaro's apparent instruction to Japanese schools to cease their interactions with Chongryun schools (75). Even the implication of Abe's attempt to revise the so-called "no-war" clause of the Japanese Constitution rings differently for "foreigners" from countries such as the U.S. and Chongryun-affiliated Koreans. This revision would pave the way for a potential military clash between Japan and North Korea which would place Chongryun Koreans in an even more vulnerable position as enemy sympathizers.

Chung's reevaluation of zainichi Koreans' non-Japanese status is based on her analysis of the key events in 1952 that changed the fates of Koreans in Japan and the United States. When the San Francisco Treaty came into effect in 1952, all Koreans in Japan who were unilaterally made Japanese subjects through colonial policy lost that Japanese nationality. In the same year, the McCarran-Walter Act in the U.S. removed racial limitations to naturalization, thereby making all Koreans in the U.S. potential citizens. Despite the more privileged legal status of Koreans in the U.S., it was curiously the Koreans in Japan that gained "greater political visibility as foreign residents than Korean Americans have as citizens or potential citizens" (165). To understand this conundrum, Chung proposes examining citizenship as always being contingent upon certain categories (race, ethnicity, class, etc.), individual qualifications (language, past conduct, etc.) and particular historical circumstances such as the Cold War (150-151). For Koreans both in Japan and the U.S., "the Cold War made the costs of citizenship especially high," but while the majority of Koreans in the U.S. gained contingent citizenship, the naturalization rate is still low for Koreans in Japan who, despite their noncitizen status, "emerged as leaders of the burgeoning immigrant community and are often at the center of public debates on immigrant incorporation, Japanese citizenship, and Japanese national identity $(147,149)$. Chung offers a radical yet important perspective that citizenship does not necessarily protect minority groups and conversely, that "legal citizenship status is not always a requirement for citizenship rights and practices" (152).

After Chung's radical reassessment of the exteriority of Koreans in Japan, John Lie's final chapter, "The End of the Road? The Post-Zainichi Generation," is a sober depiction of what he describes as the "prosaic world" that zainichi Koreans inhabit today, free from the direct racism and severe poverty they used to experience. Lie's chapter sits uncomfortably at the closing of the book since his views are directly opposed to those of the other contributors. While it is important to acknowledge the improved status of Koreans in Japan, Lie's generalized assessment of the waning legacy of "colonial past and colonial racism" does not resolve concerns over the increasingly hostile environment for Chongryun members or the inability of naturalized Koreans to feel "at home" even after gaining Japanese citizenship (168). Lie highlights the differences among zainichi Koreans that are exemplified by the diametrically opposed views of Kang Sang-jung and Tei Taikin, two vocal ethnic Korean intellectuals. Kang seeks to claim a place for zainichi Koreans outside the Japan-Korea binary in favor of the dias- 
poric identity, while Tei advocates for naturalization. It is hard not to notice a similar divide running between Ryang and Lie. Kang and Ryang both envision diasporic subjectivity outside nation states, but in the discursive and utopian site of the first generation's memory (Kang) or the idea of "homeland" (Ryang). Lie does not openly identify with Tei, but he shares Tei's reservation towards identity based on past memory and his preference for an open-ended notion of an unpredictable future self. Lie is right to caution us of the danger of "facile sociological generalizations," but his turn to individualism and open future possibilities appears equally facile. As long as we are writing/reading about, rather than living as, Koreans in Japan, we cannot seek an easy way out of grappling with Morris-Suzuki's conundrum of individualism versus determinism. 